\title{
Blend-dictionaries in a semiotic-cognitive perspective: an Active learner's construction-combinatory thesaurus «TRAVELLING»
}

\author{
Ye. I. Plakhotniuk \\ Kyiv national linguistic university, Kyiv, Ukraine \\ Corresponding author. E-mail: euegeneplakhotniuk@gmail.com, ORCID: 0000-0002-4413-1112
}

Paper received 14.11.20; Accepted for publication 27.11.20.

https://doi.org/10.31174/SEND-Ph2020-241VIII72-10

\begin{abstract}
This article introduces a novel kind of a blend-dictionary, namely, an active learner's construction combinatory thesaurus (ALCCT). The current typological classifications of lexicographical sources are challenged by the emerging hybrid and blend-dictionaries integrating several lexicographic genres. The present research offers a semiotic-cognitive model underlying such integration and, thus, systematizing their typological features. The study aims at outlining the key components of ALCCT based on the model and provides some examples of lexicographic blending from the ongoing project on the compilation of ALCCT «TRAVELLING».
\end{abstract}

Keywords: dictionary, blend-dictionary, combinatory thesaurus, cognitive lexicography, lexicographic semiotics, lexicographic typology.

Introduction. The contemporary lexicography is in the process of transition from the interdisciplinary $[28 ; 5$, p. 7 ; 11, p. 91] to transdisciplinary projects attempting at bridging the methods from several distinct scientific fields and, thus, creating a new synthetic framework for lexicographic coding [ibid., p. 94-95; 40]. According to J. Bernstein, since the times of J. Piaget who coined the term «transdisciplinary», it has turned to denote a novel paradigm in scientific research concerned with creative solutions of highly complex problems requiring the convergence of several methodologies and involvement of stakeholders [4]. Compiling a dictionary is but one of such complex problems involving not only the linguistic aspects of data processing but also profiling the intended user as well as accounting for the technical nuances of data collection and presentation. Yet, how paradoxical it may seem, the discipline concerned with defining words and unveiling the concepts behind them remains fairly speechless when it comes to explaining the essence of «dictionary» the notion central to the whole field. The problem goes far beyond the trivial discussion of a perfectly generic definition or the variety of the names given to the term $[3 ; 33]$. Indeed, it is a realistic metalexicographic conception of DICTIONARY as a phenomenon [cf. 11, p. 237] that is expected to accounting not only for the pure types of reference works but also the multifunctional sources referred to as hybrid dictionaries [13]. The examples of the emerging lexicographic hybrids which combine several dictionary genres (Hartmann\&James 1998, p. 69 cited in [13]) are numerous, e.g. 'dictionary-cum-atlas', 'dictionary-cum-encyclopaedia', 'dictionary-cum-grammar', 'dictionary-cum-thesaurus', 'dictionary-cum-usage guide', and 'monolingual-cum-bilingual dictionary' etc. [ibid., p. 195-197]. Their extended functional capacities may be of particular relevance to those who master foreign languages [12, p. 56]. Still, identifying their place within the traditional typological classifications of lexicographic reference sources and finding the proper combination of methods for their compilation seem to be a rather challenging endeavour for the existing reductionistic frameworks [cf. 13]. Furthermore, some of them require even higher degree of typological and methodological hybridisation, or blending. Namely, combinatory thesaurus as a combination of ideographic and combinatory dictionary genres needs an integrative approach to semantic-syntactic description lemmas and structuring of information.

The present research continues the discussion initiated by R.R.K. Hartmann on lexicographic hybrids [ibid., p. 205] in the light of a transdisciplinary semiotic-cognitive approach to the emerging blend-dictionaries. The study aims at introducing the Active learner's construction-combinatory the- saurus (ALCCT) as one of such blends on semiotic and cognitive grounds. The object of the research deals with the lexicographic blending in the combinatory thesauri and an ALCCT as a kind of it. The subject of the study concerns the methodological and typological aspects of blending in ALCCT «TRAVELLING». Hence, the article offers a unifying semiotic-cognitive model of the thesaurus that (i) systematizes the key metalexicographic concepts, (ii) underlies the typological classification and (iii) serves as a methodological model of compiling blend-dictionaries. Finally, the convergence of ten distinct types of dictionaries in a single product is exemplified with the data from the ongoing project on ALCCT «TRAVELLING».

1. The metalexicographic concept of DICTIONARY. There have been numerous surveys attempting at identifying the generic concept of dictionary as a phenomenon, establishing its key components and their typological variations $[5 ; 12 ; 13 ; 14 ; 28 ; 31 ; 33]$. Most often the scholars approach this task from the ontological [cf. 5], purely linguistic [31;33] or function perspectives [28]. Thus, in some definitions, the material carrier of information, be it a book or software, serves as a generic term to embrace the concept of the lexicographic reference source in its generic meaning [cf. 3]. The others view dictionary exclusively in terms of the data it handles; for the compilers of the classical wordbooks of the previous century, the dictionary is a language per sei or, at least, a complex model of language, a degree of modelling a certain language and a certain standardized version of language [ibid]. Quite the opposite view is shared by the representatives of the so-called theory of lexicographic functions, i.e. dictionary is a utility/information tool bridging lexicography as an independent discipline with the framework of information sciences [28; 3].

There are also several conceptions following the textual and communicative perspectives. On the one hand, the dictionary is viewed as a text about linguistic signs and/or a systematic and structured assembly of micro-texts on various information types concerning the lemmas [16, p. 21]. The further attempts at bridging lexicography with the text linguistics can be traced in extrapolating the textual categories onto the lexicographic texts most often without any added value in practice [10, p. 231-248]. Furthermore, it remains rather unclear what makes a lexicographic text differ from all the other texts. Obviously, dictionaries have a certain multilevel structure determined by some inner and outer factors leaving little, if any, place for the compiler's creative imagination; the interaction with the user is hardly the same as with the reader and the multiple interpretations of the dictionary entry are highly undesirable. On the other hand, the 
dictionary is a specific kind of a communicative act $[22, \mathrm{p}$. 15] which takes place between the compiler and the user [5]. However, in reality, it is the author of the linguistic sign/conceptualizer whose voice is given way in the dictionary-mediated communication [6, p. 237]. Perhaps, this is a milestone in making lexicographic texts more comprehensive and cognition-oriented. No matter how these metalexicographical conceptions differ in the sets of components pivotal for dictionaries, none of them seems to explain how they are interconnected and inderdetermined.

II. Semiotic-cognitive perspective and a unifying model of DICTIONARY. It seems possible to approach the metalexicographic concepts in a more systematic way combining cognitive and semiotic perspectives on dictionary and lexicographic coding [40]. From the semiotic point of view, the dictionary is perceived as a cultural artefact [2], a macrosemiotic object or a metatext-macrosign which has its own FORM, FUNCTION and MEANING divergent from the corresponding constituents of the linguistic signs it handles, the information carrier it relies on and the actual user interpretations (see fig. 1).

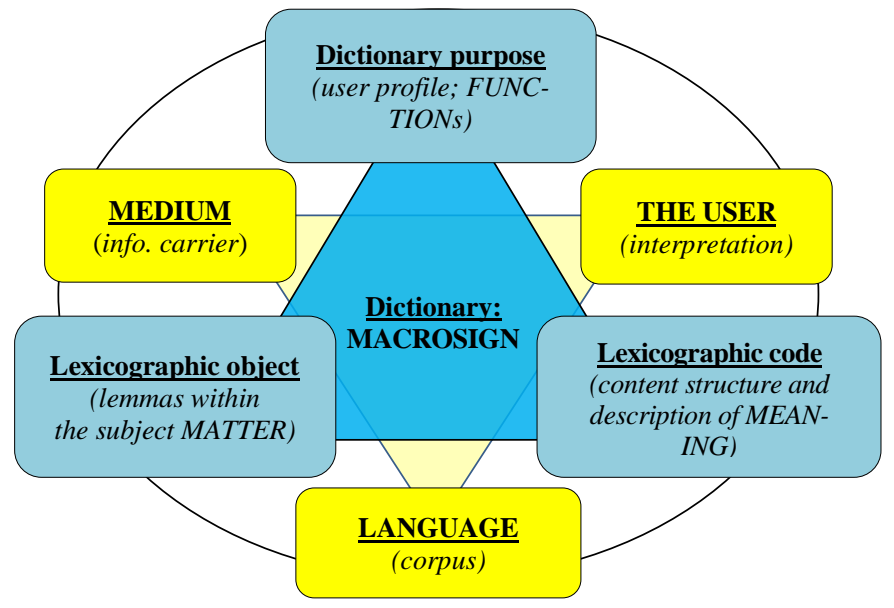

Fig. 1. A semiotic-cognitive model of dictionary: the key components and constituents.

The formal, functional and conceptual dimensions of the lexicographic text are determined by the three components of the dictionary, i.e. language, medium and the user which can be defined as distinct semiotic systems. The macrosign integrates and re-codes the information of each of them. Firstly, it has a lexicographic object which is not the same as a lexicographically processed language. It is rather a certain subject area or a limited scope of language selected and processed in accordance with the intended user profile and the capacities of the information carrier. Secondly, the purpose of dictionary as the sum of its functions implies a number of strategies of catering for its user primary, secondary and tertiary needs [cf. 28]. Finally, the selected subject matter and the functions are implemented in the lexicographic description of lemmas and a data-driven and useroriented content structure by a methodological machinery referred to as lexicographic code / metalanguage. Hence, the dictionary brings together the intended user profile, the data and the conceptualizer. The latter serves as the main source of information on macrosign meaning, i.e. the conceptual structure underlying the overall structure of the dictionary and its description of lemmas reveals the picture of the world as viewed by the native speaker and fixed in linguistic signs [cf. 6].

From the cognitive standpoint, dictionary seems to be a cognitive artefact the main function of which is representa- tional, i.e. revealing and modelling schematic representation of cognition through language and handling linguistic signs in a way compatible with the user innate information processing and learning [40]. Although the term is borrowed from the field of intelligent agents [15, c. 471] and the extended mind theory [7], it is applicable to the studies within the framework of cognitive lexicography [40]; the latter explores the possibilities of creating cognition-oriented learning tools by bridging the relevant finding in the cognitive sciences with the lexicographical praxis. Namely, the schools of cognitive linguistics allow the compilers to employ several approaches to modelling a native-like language-bound conceptualization in the dictionary and, thus, guiding the interpreter to the necessary and the only desirable understanding of lemma [cf. 6; 19; 30].

There are several implications of the semiotic-cognitive model for lexicography. On the one hand, it lays a solid foundation for the concept of DICTIONARY and systematizes the lexicographic typology. Instead of devising unsystematic criteria for the emerging hybrid dictionaries, the identification of a new type or kind of lexicographic source can follow the same inherent constituents of macrosign. The idea is compatible with what Russian lexicographer V. Morkovkin calls the three universal grounds for classification: «WHAT-ground», «WHO-for ground», «HOWground» [39: 13-23]. In our case, the model offers empty slots to be filled in with respect to the corresponding criteria for each of them, e.g. classification of dictionaries according to the lexicographic object includes various qualitative and quantitative characteristics of subject matter, nature of registered units, and perspective of their linguistic study etc. whereas for the lexicographical structure it is the organization of micro-, medio-, macro, and mega-structure that matters most. Thus it is possible not only to delineate the major lexicographic types but also classify the subsequent kinds of dictionaries within each of such types based on the same criteria throughout the taxonomy. On the other hand, the model encourages better integration of hybrid dictionaries demonstrating to what extent each of the components it is involved at each step of the compilation process. The further discussion of this idea concerns the analysis of learner's combinatory thesauri as lexicographical hybrids.

1. HYBRID DICTIONARIES: Combinatory thesaurus. The notion of a hybrid dictionary implies the combination of several typological features in one or two positions of the semiotic-cognitive model; these are predominantly the lexicographic object and some aspects of lexicographic code [cf. 13]. One of such hybrid dictionaries is a combinatory thesaurus (CT) registering keywords and co-occurring patterns as well as bridging their paradigmatic and syntagmatic properties in its description and, sometimes, structure. However, not all attempts at mixing several dictionary types result in a new type for the lack of integration in the way the lemmas are processed and coded. For instance, elaborating the traditional alphabetical combinatory dictionaries with micro-thesauri-cross-reference fields of synonyms or related terms in a so-called dictionary-thesaurus (e.g. Longman Collocations Dictionary and Thesaurus (2013)) do not demonstrate significant alterations on the part of their overall structure, entry design and the description of lemmas. The same is true for mixing the dictionaries of collocations with micro-thesauri or traditional explanatory dictionaries with the information on the combinatory properties of the lemmas (e.g. The Ukrainian-English Collocations Dictionary (2021) by Y.I. Shevchuk (in print)). The central problem lies in the 
limits of conventional linguistic methodologies when it comes to modelling the semantic-syntactic continuum of language dealing with paradigmatics and syntagmatics of the linguistic units at each level of language hierarchy.

The syntagmatic properties of linguistic signs have mostly been explored in the realm of combinatory lexicography focusing on the compilation of combinatory dictionaries or dictionaries of collocations and multiword expressions [32]. Apart from the generally recognized criteria of classifying such dictionaries, the types of valence and kinds of cooccurring units are often considered. Namely, there are dictionaries of syntactic valence registering colligations and those systematizing logical and semantic valence of words actualized in collocations (Степанова 1978, c. 157 cited in [32]), e.g. the BBI combinatory dictionary of English: a guide to word combinations (1987). In practice, however, usage-based lexicography recognizes a gradual continuum of co-occurrent patterns including idioms and idiomatic expressions as well as free word combinations and typical ways of associating and combining words [ibid.]. The unifying methodology for the lexicographic treatment of these heterogeneous units comes from the framework of construction grammar or, more precisely, constructionography [19]. Construction is a conventional form-meaning pairing or a set of rules licensing such couplings [ibid., p. 2-3]. While the constructional forms may vary greatly ranging from the morphemic to textual level, the constructional meaning is schematic and enables finding common paradigmatic properties for the hierarchical organisation of constructions and their instantiations, e.g. dictionaries of constructions in English, Swedish, Brazilian Portuguese, Japanese, German [ibid., p. 2, 8].

Paradigmatically language has been described most precisely within the genre of idiographic lexicography concerned with the compilation of thesauri or idiographic dictionaries $[1 ; 36 ; 38]$. Although some scholars view the terms «thesaurus» in the light of the alphabetically arranged dictionaries aimed at the most overall description of language [cf. 27, p.142-143], that is the onomasiological arrangement of its lemmas and the explicit fixation of the semantic relations between them [36, p. 148] that make thesaurus stand out. All the lemmas of the idiographic dictionary are described and, sometimes, structured at various levels in the direction from their meaning/conceptual structure to the forms that externalize it; hence, it seems more plausible to call such sources onomasiological dictionaries [cf. 37, p.346]. There have been numerous attempts at identifying the typological criteria for the classification of thesauri [cf. 38 , p. 22], yet the one that seems most reasonable deals with the conceptual entities underlying the semantically coherent sets, groups, and fields of linguistic units [cf. 30]. In the realm of semantic field theory [41] and contemporary cognitive linguistics [9] the entities determining self-organization of language may range from the integrative concept and a conceptual category to the conceptual domain, i.e. a coherent area of conceptualization that serves as the background for understanding the meaning of individual units [17, p. 488]. The concepts underlie lexico-semantic groups of units with synonymous or antonymous relations shuffled in dictionaries of synonyms. The conceptual category implies a hierarchical organisation of lexico-semantic fields based on a common categorial meaning and taxonomic (i.e. part-whole /kind-type) relations between units registered in the traditional idiographic thesauri (e.g. Roget's Thesaurus of English Words and Phrases P. M. Roget, G.W. Davidson (2003)). Most often such units belong to the same part of speech, i.e. either noun or adjective and verb, e.g. CLOTHES, COLOURS, VERBS OF MOTION etc. The conceptual domain is the most complex entity underpinning the organisation of the units with the heterogeneous relations into a certain semantic (thematic or associative) fields. Such fields can include units of various parts of speech and language levels; they can come from a general or special language domain, e.g. RELATIONSHIPS, SHOPPING, THEATER, TOURISM, INTERNATIONAL RELATIONS etc. There are three main kinds of thesauri to handle the domainspecific information: associative, thematic and conceptualontological. The associative thesauri establish relations between the members of the field employing a psychoassociative experiment to reveal the intuitive associations between the stimuli and the associate. The thematic dictionaries/thesauri approach the problem of the interconnectedness of lemmas from the ontological perspective based on the actual common phenomena and their relations with the likewise realia, i.e. PARTS OF BODY / ANATOMY, KINSHIP TERMS, GEOGRAPHY. Finally, the conceptualontological or domain thesauri designed within cognitive lexicography establish the conceptual structure of each lemma and the relations between them based on the lingocognitive analysis of the whole field [cf. 30]. Currently, there are several methodologies at the disposal of compilers of such dictionaries including frame semantics, construction grammar [19] and semantics of lingual networks (SLN) [30]. The latter is central to our research as it helps to shuffle the linguistic signs for research and pedagogical purposes.

SLN was devised by prof. S. Zhabotynska who offered basic propositional schemas (BPS) as minimal conceptual model for the description of the lexical meaning and building conceptual ontology of any field of knowledge [cf. 30; 34; 35]. The seventeen PBS determine the most primitive categories of thought and, thus, help to identify the types of entities within any subject area. They consist of basis (X) unchangeable component, feature $(\mathrm{SUCH})$ - changeable component and the link between them [cf. 30], e.g. high season - $\mathbf{X}$ is $\mathbf{S U C H}$-qualitative; globetrotter $-\mathbf{X}$ is THERE-locative; weekender $-\mathbf{X}$ is THEN-temporative; caravan (from caravan of travellers) - $\mathbf{X}$ is THAT MANYquantitative etc. The BPS are used not only for lexical meaning but for the constructional meaning of syntactic patterns allowing transforms of the same schema, e.g. a courageous traveller- traveller's courage, the courage of the traveller etc. [34]. It is a unifying schematisation of meaning that allows bridging the two axes of the linguistic signs in the structure of a combinatory thesaurus. The prototypes of such CTs designed by the researcher and her PhD students cover such domains as HOTEL\&HOSPINALITY, MARKETING, ACADEMIC CLISHES, and a wash of learner's CT for conversational English topics [35]. The current study follows this tradition and elaborates on further integration of pragmatic axis bringing the user in [40].

IV. BLEND-DICTIONARY: Active learner's construction-combinatory thesaurus «TRAVELLING». The notion of lexicographic blending is viewed as a convergence of several typological features filling in all the positions of the semiotic-cognitive model of dictionary and effecting all the steps of the compilation process, i.e. profiling, selection, processing, presentation and use of data. Thus, to compile a blend-dictionary, the research design relies on the transdisciplinary framework of methodological triangulation bridging the methods from the relevant disciplines on language, user, and medium to formulate some research principles of 
user profiling, selection of data and building the lexicographic code. In my $\mathrm{PhD}$ project concerned with the compilation of Active learner's construction-combinatory thesaurus (ALCCT) as a blend, these principles are based on (1) the neurocognitive studies of adult learners of foreign language and language production for user profiling, (2) lingocognitive studies of linguistics signs and fields for lexicographic coding, as well as (3) lingodigital tools and methods for corpus-based data selection and presentation. As the result, the typological model of ALCCT integrates at least ten different features of its mono-functional counterparts (see fig.
2.) with each of them being taken into account at each step of the compilation process. Namely, the thesaurus is a blend of pedagogical dictionary [21], L2 production-oriented (active) dictionary [24], corpus-based frequency dictionary [8], thematic dictionary [26], combinatory dictionary [23], dictionary of synonyms [29], constructicon [19], ontological thesaurus [20], dictionary of idioms [25] and lingo-encyclopaedic thesaurus [18]. The further discussion of integrating these features follows the steps of compiling ALCCT «RAVELLING» as reflected in its semiotic-cognitive model below.

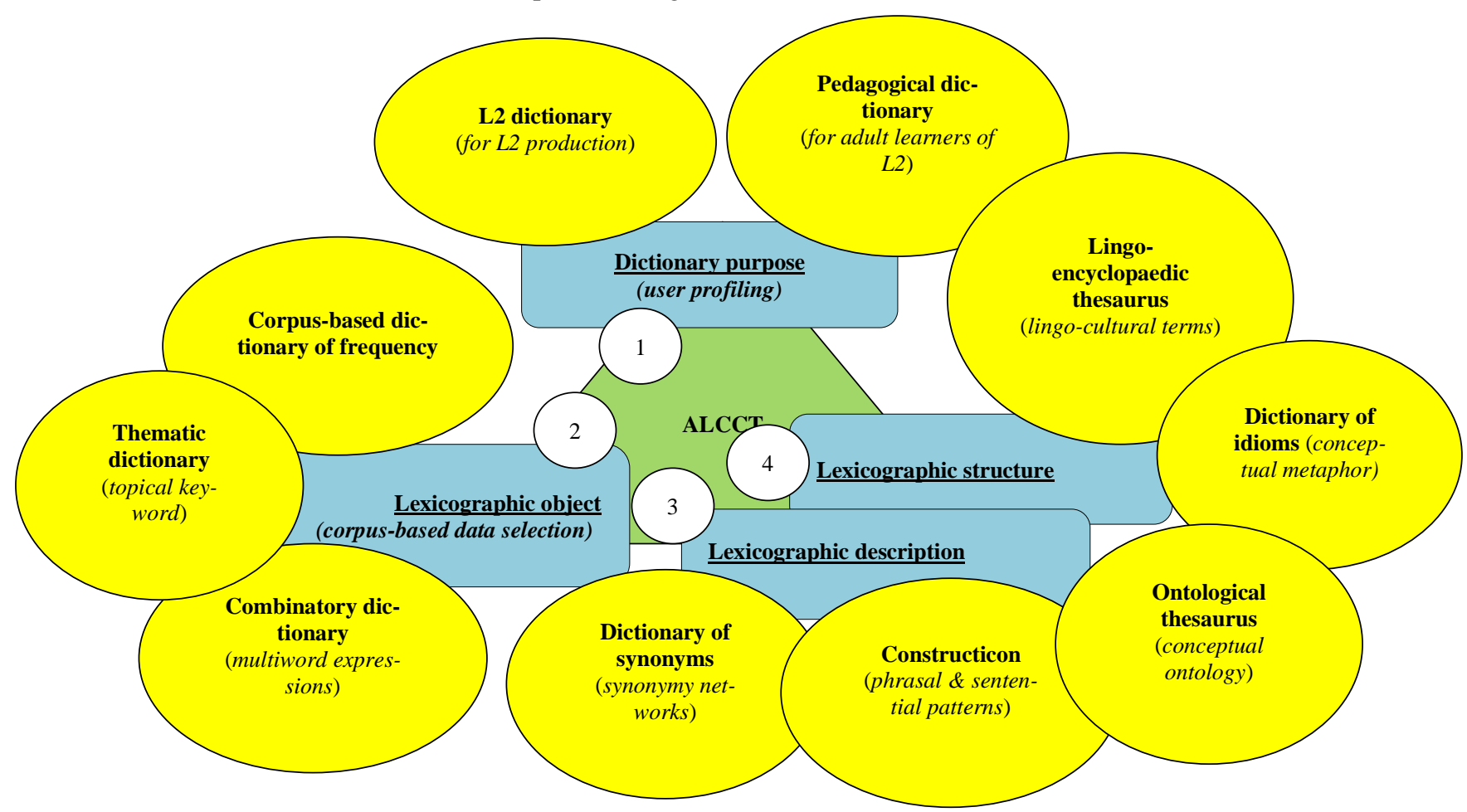

Figure 2. ALCCT: lexicographic blending

4.1. ALCCT «TRAVELLING» purpose. ALCCT is designed as a pedagogical and L2 production-oriented dictionary $[21 ; 24]$ which in our case implies following the user perspective on neurocognitive and lingodidactic grounds. The thesaurus aims at assisting adult learners in L2 production, i.e. speaking and writing. To make it more userfriendly, the compilation process starts with the user profiling - a questionnaire-based identification of primary, secondary, and tertiary user needs as well as the formulation of compiler's strategies of catering for them in the light of neurocognitive researches on adult L2 learning, i.e. cognitionoriented data selection, arraignment, presentation and use. As the results of user profiling suggest, the intended user of ALCCT «TRAVELLING» is likely to look for the most topical words and phrases on this conversation English topic. The lemmas are expected to be organized in a coherent and cohesive content structure providing the onomasiological access to the information and encouraging native-like conceptual planning and encoding of the event TRAVELLING in user's own phrases, sentences, and texts. Finally, the adult users have an inclination of the immediate application of their new knowledge to practice, i.e. making their own sentences and texts. Hence, ALCCT offers several tools for enhancing cognitive and communicative skills through content-language integrated learning of a certain domain and guiding the users through the most typical communicative situations.

4.2. ALCCT «TRAVELLING» lexicographic object.
The data collection rests on a special corpus of the authentic English texts covering the conversational English domain of TRAVELLING. The sources include the texts representing TRAVELLING in the most prominent genres such as travel guides, travelogues, travel stories, travel blogs/vlogs, trip advisories etc. Other texts on the profession domain TOURISM covering English for specific purposes are deliberately ignored. The topical keywords and co-occurring units (i.e. phrases and sentences patterns) constitute the core of ALCCT database and serve as lexical and phrasal lemmas correspondingly. They are retrieved from the corpus based on their frequencies, semantic coherence and combinatory productivity.

Similarly to the thematic dictionaries [26], the ALCCT accumulates the linguistic units of various parts of speech within a subject area externalising a conceptual domain. It is, therefore, crucial to follow not the compiler's logic but the data reflecting the native-like annotation of the thematic or notional classes and categories of words. The analysis proves a certain degree of semantic attraction of such words as $a$ traveller, accommodation, destination, local, ticket, to book, overseas, to journey, to board, away, wanderlust, to depart, to sail and a great number of others within the topic «TRAVELLING». Thus, it is believed that a conceptual coherence of the input will facilitate the L 2 acquisition by users.

Still not only the keywords are important for the production of users' L2 sentences on the topic TRAVELLING. Some typical phrasal and sentential patterns are included as 
well, e.g. a prolific traveller, travel expenses, exotic destinations, traveller's check, itchy feet, on the road, on budget, to book a hotel, to buy a ticket, to apply for a visa, to hit the road, farewell etc. As a combinatory dictionary [23], ALCCT handles a wide range of co-occurrent units (multiword expressions, collocations and colligations) that actualize various types of semantic, syntactic and lexico-semantic valence of words. Establishing the relations between the nucleus and the satellite component of such expressions in a systematic semantic-syntactic way is supposed to make the overall arrangement of the combinatory thesaurus more holistic and enhance acquisition of lemmas.

As a frequency dictionary [8], the thesaurus registers lemmas and marks their status on the ground of a quantitative (frequency-based) and qualitative (context-conceptual, distributional) analyses. The former deals with keyness of lexical and phrasal lemmas and identifies the three levels of lemma priority within each of semantically coherent group or set. For instance, the group of synonyms externalizing the concept TRAVELLER with the conceptual descriptor of STpurpose (leisure) is split into: a) top frequency words marked with red: tourist; b) less frequent marked with green: holidaymaker and c) the rest coloured in blue and ordered according to the descending frequency status: tripper, vacationer, weekender, daytripper, excursionist, tourer, vacationist, holidayer, voyager, trekker, journeyer, journeyman. The same marking is applied to phrasal lemmas to avoid the information overload of users and meet the three levels of L2-domain proficiency. Hence, frequency is used for selection, arraignment, presentation and further use of data.

4.3. ALCCT «TRAVELLING» lexicographic structure and description. The thesaurus under investigation follows the onomasiological principles of data arrangement and integrative description. For this, the content structure of ALCCT involves the key four structural levels on lingocognitive grounds [34;35]: macro-, medio, micro- and megastructures.

The microstructural level of ALCCT determines the entry design for lexical and phrasal lemmas. Both keywords and phrases as headwords are provided with a translation equivalent in the native language (in our case Ukrainian), a sematic BPS-structured definition, an example of usage form the corpus, a set of cross-references for semantic variations and constructional transformations as well as illustrations and encyclopaedic notes, if necessary. For instance, the lemma backpacker is gived as follows: (Ukr.) піший турист / мандрівник, який подорожус пішки 3 рюкзаком за плечима: Weight is the enemy of the backpacker (OBannon, 2001, p. 20). When I was a truly destitute backpacker I could barely scrape together money for food, let along souvenirs, so this won't hold true for everyone, but if you've got the money, spend it (Traveller, 2019); Syn. flashpacker; Ant. light traveller See also: a backpack, a backpacking trip/ holiday, to backpack, to go backpacking. At first glance, ALCCT is a typical bilingualised monodirectional dictionary for L2 learners. However, it is the cognitive definition that grounds samantisation in line with a usage-based framework and helps to account for the nonequivalent cases as fleshpacker, daytripper, jet-setter etc. To establish the conceptual structure of each lemma, the research relies on a mediostructure.

The mediostructural level is central to ALCCT as far as it systematized the semantic and syntactic relations across the whole thesaurus and each coherent group/set. Namely, it involves the two key components: the networks of synony- my and the construction-combinatory portrait of keywords. Both synonymous keywords and phrases are handled similarly to the dictionaries of synonyms but in a more systematic way. Specifically, each network of synonymous lemmas organizes them into groups with respect to their BPSstructures and subgroups in line with their integrative conceptual descriptors. The network «TRAVELLER» has several BPS-based groups and conceptual subgroups, e.g. the group representing the schema $\mathbf{X}$ travels by SC (instrument) includes subgroups with such descriptors as TRANSPORT (in general) - passenger, driver, fare; FOOT - pedestrian, hiker, walker, stroller, tramper, passerby; SHIP: sailor, mariner, cruiser, shipman; PLANE - pilot; WHEELS - motorist, motorcyclist, wheelman, hitchhiker; PUBLIC TRANSPORT - straphanger. Other groups may include different sets of conceptual descriptors including TIME, DIRECTION, PURPOSE etc. Still, it is the dominant schema that serves as a common ground for all of the units within a group. The same logic is applied to the phrasal lemmas within each syntactically defined set. Similarly to the dictionaries of constructions, ALCCT considers all cooccurant patterns (phrases or sentences) as constructions, i.e. conventionalized and L2 legitimate pairings of form and meaning [19, c. 2-3]. The constructional meaning is schematized by BPS whereas the formal structures (phrasal and sentential) are arraigned separately. The former organizes the satellite phrases around a prioritized concept, i.e. the most prominent keyword that serves as a nucleus and groups them into sets according to their syntactic patterns: $\left(\operatorname{AdjN}_{1}(a\right.$ prolific traveller), $\mathrm{N}_{1} \mathrm{~N}_{2}$ (traveller cheque), $\mathrm{N}_{2} \mathrm{~N}_{1}$ (budget traveller), $\mathrm{N}_{2} \mathrm{PN}_{1}$ (the influx of travellers), $\mathrm{N}_{1} \mathrm{PN}_{2}$ (destination of one's choice), $\mathrm{VN}_{1}$ (to guide a traveller, $\mathrm{N}_{1} \mathrm{~V}\left(\mathrm{PN}_{2}\right)$ (traveller travels overseas). The patterns of sentences are handled within a megastructure as an additional level built over the portraits.

Networks of synonymy and construction-combinatory portraits determine the arrangement of lexical and phrasal entries correspondingly. Moreover, they establish the semantic variants and constructional transformations included into the corresponding cross-reference fields of each individual entry, e.g. budget traveller includes SYN. savvy traveller, moderate traveller; ANT. affluent traveller, luxury traveller, wealthy traveller; TRANS. to travel on budget, a budget travel, travel budget, traveller's budget. Thus, ALCCT enables users' semantic and syntactic periphrasis of their own words and phrases.

Macrostructural level is built over the previous two in the process of the conceptual analysis of the prioritized keywords and on the ground of their syntactic and semantic relations. The model of multilevel data arrangement as a «network-in-networks» has been offered by prof. S.A. Zhabotynska [30]. The scholar identifies such four levels as conceptual space - the network/matrix of domains, domain - the network/matrix of parcels, parcel - the network/matrix of prioritized concepts, and concept - the network of secondary concepts and conceptual attributes [cf. ibid, p. 81; 34; 35]. In ALCCT, the macrostructure is designed only after the structuring of lemmas on the previous levels has been accomplished. As the conceptual analysis of corpus-based data indicates, the conceptual ontology of ALCCT «TRAVELLING» has four domains - (1) TRAVELLER, (2) TRAVEL, (3) DESTINATION, (4) TRAVEL AGENTS. Each of the domains has a number of parcels, e.g. TRAVELLER includes TRAVELLER proper, HOME, TRAVEL TIME, TRAVEL BUDGET, TRAVEL DOCUMENTS, LUG- 
GAGE, and FELLOW TRAVELLERs; TRAVEL involves TRAVEL proper, TRANSPORTATION and ROUTES/ITINERARIES; DESTINATION encompasses DESTINATION proper, ACCOMMODATIONS, ATTRACTIONS, ACTIVITIES, LOCALS, DISCOVERIES, and SOUVENIRS; TRAVEL AGENTS relate to TRAVEL AGENCIES\&AGENTS, TRAVEL SOURCES, and TRAVEL SERVICES/OPTIONS. Each parcel has one or more prioritized concepts portrayed at the subsequent mediostructural level, e.g. TRAVELLER proper has a homogenous network of such concepts, as TRAVELLER, TOURIST, PASSENGER, VISITOR, EXPLORER, and BACKPACKER. The rest of the concepts are grouped as secondary in the networks of synonymy. The identification of superordinate levels of conceptual hierarchy relies on the subordinate concepts and groups of concepts externalised in lexical and phrasal lemmas. Hence, similar to the ontological thesauri, the hierarchical structure of ALCCT provides a better onomasioligical access of data and structural coherence of the content.

Megastructure of ALCCT extends the previous levels with the additional components, i.e. (1) lingo-encyclopaedic notes of idioms and (2) culture-specific concepts as well as (3) a syntactic constructor - a set of sentential patterns. The first deals with the mechanism of cognitive metaphor/metonymy and uses the thesaurus macrostructure as a referential domain for a conceptual cross-domain network of idiomatic expressions. Unlike the traditional dictionaries of idioms [25], ALCCT handles such units according to their meanings, revealing the mechanisms of their motivation and, thus, helping the users to learn new idioms and create their own metaphors when talking on several correlative topics in terms of the referential topic TRAVELLING, e.g. LIFE is A JOURNEY, LOVE IS A JOURNEY, FAITH IS JOURNEY, CAREER IS A JOURNEY, MENTAL PROCESS IS A JOURNEY, NARRATION IS A JOURNEY etc. For instance, the expressions externalizing the cross-mapping of the correlational domain LIFE onto the referential domain TRAVELLING results into a hierarchy of subordinate pairings with subgroups within each of them: DESTINYTRAVELLING (FORTUNE - VEHICLE: to turn the wheel of fortune, to ride a gravy train), FORTUNE TRAVEL DOCUMENT: a ticket to a decent / new life; a golden ticket; a meal ticket); PERSON-TRAVELLER (PERSON-VEHICLE: like the ships in the night, train wreck; PERSON-TRAVELLER: bird of the passage, man of the world). Thus, the users can apply their knowledge of the topic TRAVELLING in metaphorical speaking and creative writing on an array of correlating topics.

The second component is built over the microstructural level. It handles the lingual networks of culture-specific concepts similarly to the encyclopaedic and linguacultural dictionaries [18], e.g. PILGRIM, GREEN TRAVELLER, DIGITAL NOMAD, FLESHPACKER etc. Such units signify realia and entities distant to the non-native speakers of English. They have a set of heterogeneous conceptual attributes and special narration patterns that goes beyond the standard entry design. For instance, the conceptual structures of the terms PILGRIM and PILGRIMAGE deals with the specific nominalisations of AG-TRAVELLER ( $a$ wanderer, a palmist, a pilgrim, enlighten man, the knight of the road, Muhammad etc.), the variety of its conceptual attributes (X acts lacts upon (makes a pilgrimage, undertakes arduous journeys, embarks upon perilous journeys, takes the cross, plots one's route, traverses on foot to, gets lodging at the monasteries along the road, stays in tavern, seeks shelter etc.)), the sacred Lc-DESTINATION (the tomb of the apostle, sacred land, Jerusalem, Rome, Santiago, Mecca, Medina etc.), a special Lc-PATH (a sacred route, the road to Compostela, the Milky Way etc.) and Md-MANNER (on foot), peculiar SC-LUGGAGE ITEMS ( a palm, the scallop shell, a gourd, a three-cornered hat, cape, a shepherd's crook, a knapsack etc.) and SC-FELLOW TRAVELLERS (monks, priests, ) as well as distinguished ST-PURPOSES (for religious reasons, to pay homage to the saint, to find oneself, to achieve insight, to learn the RAM practices, to find the sward, to seek a miraculous cure for an illness, to fulfil a vow to a saint etc.). In ALCCT such units are organised in the conceptual networks facilitating the understanding of the key concept and, thus, resembling the arrangement of conceptual thesauri or dictionaries of concepts designed within the network of conceptography. Such lingual networks not only provide the most vital information on each entity but also serve as a visual support for users in building their own narration, i.e. reports, stories, essays etc.

The final component is a syntactic constructor extending the mediostructure of ALCCT (i.e. basic phrasal constructions) with the simple and complex sentential patterns. Based on the corpus of texts about TRAVELLING, the most typical communicative situations are retrieved, analysed, grouped and modelled as script models, e.g. AT THE TRAVEL AGENT, AT THE AIRPORT, ON BOARD, CHECKING-IN, ASKING FOR DIRECTION, BUYING SOUVENIR ect. Each script has several scenarios with each involving several steps. Each step has a set of syntactic patterns visualized as a syntactically linked sequence of open semantic slots, i.e.:

- WHERE (DESTINATION) would YOU (TRAVELLER) like
to $G \boldsymbol{O}_{\text {(TRAVELLER acts) }}$ ?
$-\quad I_{\text {(TRAVELLER) }}$ want to SPEND (TRAVELLER acts upon) $m y$ VACATION (TRAVEL TIME) somewhere in SPAIN (DESTINATION). $\boldsymbol{W H A T}_{\text {(DESTIONATION) would }}$ YOU (T.AGENT) RECOM$M E N D_{\text {(T.AGENT acts) }}$ ?

Each pattern can be filled in with a number of synonyms according to the conceptual descriptor in brackets but for the words highlighted in bold, e.g. I/he/she (TRAVELLER) would like to take a tour/book a trip/make a journey (acts upon TRAVEL) to Japan/around Europeloverseas (DESTINATION). The users are encouraged to play roles and fill in the slots with as many synonyms as they wish to practice communication. Another type of scripts are represented as algorithms of text models aimed at facilitating users' narration in their oral and written stories, essays, report, letters, comments etc., e.g. WRITING COMPLAINT, THANK YOU NOTE, TRAVEL BLOG STORY, SHARING TRAVEL TIPS, WHAT IS IN MY BAG etc.

Thus, the lexicographic blending of ALCCT «TRAVELLING» relies on semantics of lingual networks, construction grammar, cognitive metaphor and conceptology bridged on the semiotic-cognitive grounds.

Conclusion. The contemporary transdisciplinary tendencies in lexicography bring to the fore the problem of a unifying framework for the methodological convergence and typological integration. A special attention of researchers is focused on the hybridisation impacting the lexicographic theory, typology, criticism, and practice. Yet, a semioticcognitive perspective can provide even higher degree of systematic integration, i.e. lexicographic blending in compilation of ALCCT and likewise sources. The theoretical implications of the present study concern extending the current 
approaches to dictionary research and enhancing transdisciplinary collaboration. The practical implications relate to the further application of ALCCT «TRAVELLING» in teaching English as a foreign language to adult learners.
1. Aitchison J., Gilchrist A., Bawden D. (2000). Thesaurus Construction and Use: A Practical Manual. Psychology Press.

2. Annoni, M. (2014). Culture, power, dictionaries: What lexicography reveals about cultural objects, Semiotica, (198), pp. 261-269.

3. Bergenholtz H. (2012). What is a Dictionary? Lexikos. pp.20-30.

4. Bernstein, J. (2015). Transdisciplinarity: A review of its origins, development, and currenti. Journal of Research Practice. 11.

5. Beyer, H. \& Augart, J. (2017). From User Questions to a Basic Microstructure: Developing a Generative Communication Theory for a Namibian German Dictionary. Journal for Studies in Humanities and Social Sciences, №6. P.1-31.

6. Bothma W. J. (1996). Cognitive framework of a set of crecket terms. Cognitive Linguistics in the Redwoods, Berlin: Mouton de Gruyter, P. 237-247.

7. Clark, A., Chalmers D. (1998). The extended mind. PhilPapers.

8. Davies M., Gardner D. (2010). A Frequency Dictionary of Contemporary American English. Word sketches, collocates, and thematic lists. NY: Routledge.

9. Dirven R., Verspoor M. (1998). Cognitive exploration of language and linguistics. Philadelphia: Benjamins.

10. Frawley W. (1989). The Dictionary as Text. In International Journal of Lexicography, pp. 231-248.

11. Fuertes-Olivera P. A. (ed.) (2018). The Routledge Handbook of Lexicography. London: Routledge.

12. Gouws, R.H. (2010). The monolingual specialized dictionary for learners. In Fuertes-Olivera, P.A. (ed.): Specialised Dictionaries for Learners. Gruyter, pp. 55-68.

13. Hartmann, R.R.K. (2005). Pure or hybrid? The development of mixed dictionary genres. Facta universitatis. Series: Linguistics and Literature. Vol. 3, No 2, pp. $193-208$

14. Hartmann, R.R.K., James G. (1998). Dictionary of Lexicography (ed.). London/ New York: Routledge.

15. Heersmink, R. A. (2013). Taxonomy of Cognitive Artifacts: Function, Information, and Categories. Review of Philosophy and Psychology. Springer Verlag, №4. pp. 465-481.

16. Landau S.I. (2001) Dictionaries.The Art and Craft of Lexicography. Cambridge University Press.

17. Langacker R.W. (1987). Foundations of cognitive grammar. V. 1: Theoretical prerequisites. Stanford, CA: Stanford University Press.

18. Lowry L.L. (2017). SAGE international encyclopedia of travel and tourism. Sage Publications.

19. Lyngfelt B., Borin L., Ohara K., Torrent T.T. (2018). Constructicography: Constructicon development across languages. Constructional Approaches to Language..

20. Miller, G., Beckwith, R., Fellbaum, Ch., Gross, D.k \& Miller, K. (1991). Introduction to WordNet: An On-line Lexical Database. International Journal of Lexicography, 3 (4). pp. 235-244.

21. Nesi H. (2012). The Use and Abuse of EFL Dictionaries: How Learners of English as a Foreign Language Read and Interpret Dictionary Entries. De Gruyter.

22. Peng J., Yong H. (2007). Bilingual Lexicography from a Communicative Perspective (Terminology and Lexicography Re- search and Practice). John Benjamins.

23. Peterson Education (2013).Longman Collocations Dictionary and Thesaurus. Pearson Education ESL.

24. Rundell, M. (1989). Dictionary use in production. International Journal of Lexicography. Oxford: Oxford University Press, №12, 35-53.

25. Spears R. A. (1997). NTC's Thematic Dictionary of American Idioms. McGraw-Hill.

26. Spears R.A. (1999). NTC's Thematic Dictionary of American Slang. NTC Publishing Group.

27. Sterkenburg, P.V. (2003). Onomasiological Specifications and a Concise History of Onomasiological Dictionaries, A Practical Guide to Lexicography. Philadelphia: Benjamin's.

28. Tarp, S. (2008). Lexicography in the Borderland between Knowledge and Non-Knowledge. General Lexicographical Theory with Particular Focus on Learner's Lexicography. Lexicographica. Series Maior 134.

29. Urdang L. (1991).The Oxford Thesaurus - An A-Z Dictionary Of Synonyms. Clarendon Press.

30. Zhabotynska S. (2010). Principles of building conceptual models for thesaurus dictionaries. Cognition, communication, discourse. Series: Philology, № 1. P. 75-92.

31. Апресян Ю. Д. (2006). Языковая картина мира и системная лексикография. М.: Языки словянских культур.

32. Влавацкая М. В. (2004). Лексикографическая интерпретация сочетаемости слов: Модель построения русско-английского учебного комбинаторного словаря: автореф. дис. на соиск. науч. степени канд. филол. наук: спец. 10.02.19 «Теория языка». Барнаул,

33. Герд, А. С.(1997). К определению понятия «словарь». Проблемы лексикографии: Сб. статей. СПб. С. 191 - 203.

34. Жаботинская С.А. (2018). Генеративизм, когнитивизм и Семантика лингвальных сетей. Doctrina multiplex, veritas una. Учень багато, істина одна: збірник праць до ювілею Ізабелли Рафаїлівни Буніятової.К.:Київ, ун-тім. Б.Грінченка. С. 99-141.

35. Жаботинська С. (2020). Семантика лінгвальних мереж у навчальному комбінаторному тезаурусі. Studia Philologica, №2. C. 17-27.

36. Караулов, Ю.Н. (1981). Лингвистическое конструирование и тезаурус литературного языка. М.: Наука.

37. Кубрякова Е.С. (1990). Ономасиология. Лингвистический энциклопедический словарь. М., С. 345-346.

38. Морковкин В. В. (1970). Идеографические словари. Москва: Из-во МГУ. С.12-22.

39. Морковкин В. В. (1994). Типология филологических словаpeй. Vocabulum et vocabularium. Вып. 1. Харьков. С. 13-23.

40. Плахотнюк Є.І. (2020). Когнітивна лексикографія: лінгвокогнітивні засади лексикографічного кодування. Вчені записки Таврійського національного університету мені В. I. Вернадського. Серія: Філологія. Том. 31(70), №3.,Ч.2. pp. 42-50. DOI 10.32838/2663-6069/2020.3-2/07

41. Щур Г.С. (1974). Теории поля в лингвистике. М.: Наука

\section{REFERENCES}

31. Apresian U.D. (2006). Linguistic picture of the world and systematic lexicography. Moscow: Yazyki slovianskikh kultur.

32. Vlavatskaya M.V. (2004). Lexicographic interpretation of word combinability: the model of building Russian-englush learner's combinatory dictionary. autoref. diss. na soisk. nauch. stepen kand. filol. nauk: spets. 10.02.19 «Theory of language». Barnaul.

33. Gerd A. S. (1997). Towards the definition of the notion of «dictionary». Problemy leksikografii: sb. statei, pp.191 - 203.

34. Zhabotynskaya S. (2018). Gnerativism, cognitivism and Semantics of lingual networks. Doctrina multiplex, veritas una.Uchen bahato istyna odna: zbirnyk prats do yuvileyu Izabelly Rafayilivny Buniyatovoyi. Kyiv national university of B. Grinchenka, 99 $-141$.

35. Zhabotynska S. (2020). Semantics of lingual networks in learner's combinatory thesaurus. Studia Philologica, №2. P. 17-27.

36. Karaulov U.N. (1981). Linguistic constructing and thesaurus of literary language. Moscow: Nauka.

37. Kubriakova Ye. S. (1990). Onomasiology. Linguistic encyclopedic dictionary (M., C.). Moscow. pp. 345-346.

38. Morkovkin V.V. (1970). Idiographic dictionaries. Moscow.

39. Morkovkin V.V. (1994). Typology of philological. Vocabulum et vocabularium. Issue 1. Kharkov. pp. 13-23

40. Plakhotniuk Ye. I. (2020). Cognitive lexicography: lingocognitive grounds of lexicographic coding. Vcheni zapysky Tavriyskoho natsionalnoho universytetu ivmeni V.I. Vernadskoho. Series: Filology. Vol. 31(70), №3. P.2. pp. 42-50. DOI 10.32838/2663-6069/2020.3-2/07

41. Shchur G. S. (1974). The field theory in linguistics. Moscow: Nauka. 